\title{
The Influence of Self-fertilization Performance and Copulation Behaviour in Reproduction by Cross-fertilization in Groups of Biomphalaria tenagophila (Mollusca, Planorbidae)
}

\author{
June Springer de Freitas ${ }^{+}$, Débora Pires Paula, Mariana Otero Cariello
}

Departamento de Ecologia, Universidade de Brasília, Caixa Postal 04631, 70919-970 Brasília, DF, Brasil

The following hypotheses were tested for groups of simultaneous hermaphrodites Biomphalaria tenagophila: (a) snails that have low reproductive success during the process of self-fertilization do not increase their reproductive success after the end of grouping; $(b)$ the copulation behaviour and the presence of one snail whose eggs have a low viability rate influence the partner's reproductive success by cross-fertilization. Groups were constituted by a homozygous pigmented snail and two albinos: one with a viability rate higher than 70\% ("good reproducers") and the other less than 10\% ("bad reproducers"). All pigmented snails had viability rates higher than 70\%. The "good" and "bad" reproducer albino snails had similar copulation behaviour. However, after the end of grouping, the "bad reproducers" continued to have viability rates less than $10 \%$ over 30 days. In $100 \%$ of the cases that pigmented snails copulated (performing either a male role or simultaneously male and female roles) exclusively with "good" reproducer albinos, they presented high reproductive success (producing, on average of 8.4 pigmented embryos/egg-mass). However, in $100 \%$ of the cases that pigmented snails copulated with both partners, the "good" reproducer albino snails produced none or very few embryos (the highest average was 2.2 pigmented embryos/egg-mass). Therefore, the production of viable embryos by crossfertilization was more influenced by self-fertilization performance than by copulation behaviour. The presence of a snail whose eggs have a low viability rate could decrease their partners reproductive success.

Key words: Mollusca Planorbidae - Biomphalaria tenagophila - reproductive success - copulation behaviour self-fertilization - cross-fertilization

Biomphalaria tenagophila, a snail host of human schistosomiasis, is a simultaneous hermaphrodite with the ability of self-fertilization. However, in the presence of partners, cross-fertilization is prefered (Paraense 1955).

It has been observed that self-fertilizing isolated snails kept under the same conditions in the laboratory have different reproductive rates. Before starting studies about the reproductive biology of these molluscans, it is important to know such differences.

During the course of studies on the reproductive biology of $B$. straminea, B. intermedia and $B$. peregrina, Hofmann (1987) observed that some snails that had low reproductive success during the process of self-fertilization, may have the following behaviour after mating: (a) a total inhibition of

\footnotetext{
${ }^{+}$Corresponding author. Fax: +55-61-272.3476. E-mail: june@guarany.cpd.unb.br

Received 23 July 1996

Accepted 23 June 1997
}

reproduction (total sterility); (b) inhibition of female activity; (c) inhibition of male activity; (d) some kind of blockage in the mechanisms of selffertilization, although the individual is functional for both sexes. It was also observed that many individuals with reproductive problems in self-fertilization had, in general, a satisfactory peformance in cross-fertilization. However, it was observed that in B. tenagophila, the mean number of eggs produced by snails and the viability rates before grouping were similar to those found after grouping (Freitas 1994, Dias 1995).

Bulinus cernicus specimens of similar ages and development stages, evaluated by the ability of selffertilization, showed differences in their roles' performance (Rollinson et al. 1989). The probable individual variation in the ability of snails to adopt different sexual roles requires more attention. It may be wrong to assume that all the snails in a population are equally well-balanced for tendencies to perform the female or male role. Rudolph and Bailey (1985), for example, observed that male sexual role is more frequent in populations of Bulinus. Moreover, the performance of this role is 
not dependent on previous sexual experience as male or female.

The objective of the present study is to verify the influence of self-fertilization performance and copulation behaviour in the production of embryos by cross-fertilization in groups of $B$. tenagophila.

The following hypotheses were tested: (a) snails that have low reproductive success during the process of self-fertilization do not increase their reproductive success after the end of grouping, (b) the copulation behaviour and the presence of one snail whose eggs have a low viability rate influence the partner's reproductive success by crossfertilization.

\section{MATERIALS AND METHODS}

B. tenagophila mutant albino and homozygote wild-type (pigmented) snails were used. They came from Joinville (southern Brazil), and were reared and kept at the laboratory for approximately 10 years. The snails were kept in isolation since the period of sexual immaturity and used in the experiments upon reaching a diameter of 10 to 12 $\mathrm{mm}$ and the age of 2 to 3 months. Albinism, determined by a pair of recessive genes (Newton 1954), was used as a genetic marker.

The snails were reared in the laboratory at an environmental temperature of approximately $25^{\circ} \mathrm{C}$ and fed fresh lettuce and a ration composed of equal parts of whole milk powder (300 g), earth (sterilized in a stove at $90^{\circ} \mathrm{C}$ and enriched with calcium bicarbonate), wheat germ, calcium carbonate in powder, dried and triturated alfalfa and $350 \mathrm{mg}$ of vitamin E (Freitas et al. 1975, modified). The water was refilled periodically to compensate evaporation. The individuals were isolated in a glass container of $125 \mathrm{ml}$, previously prepared with one tablespoon of earth (the same used in the ration) and $80 \mathrm{ml}$ of water without chlorine. Egg-masses were collected from Styrofoam blocks floating on each aquarium or from the wall of the glass using a spatula, transferred to wet cotton in small vials, and put in an oven kept at $28^{\circ} \mathrm{C}$. About five days later, albino and pigmented embryos could be identified.

The reproductive success was measured by the number of egg-masses, the number of viable embryos/egg-mass, and the total egg-mass and viability rate (number of viable embryos/total of eggs). The eggs were counted, under a steroscopic microscope, every two days, and classified into the following categories: pigmented, albino or sterile embryos, eggs with a hole and empty or small (less than half size of normal egg).

The self-fertilization performance of 140 snails was verified during 15 days.

The snails were divided into two groups, each consisting of one homozygous pigmented and two albino snails; one of the albino had a viability rate higher than 70\% ("good reproducer") while the other less than $10 \%$ ("bad reproducer"). The pigmented snails had viability rates higher than $70 \%$. The snails were marked individually with one piece of spangle glued in the right side of the shell. The water volume per snail was $100 \mathrm{ml}$.

The copulation behaviour was observed over a $12 \mathrm{hr}$ period after the snails had been placed in groups. The duration of each copulation and the sexual role performed by each partner were noted. The snails were subsequently isolated and the reproductive performance monitored over a 30 day period.

The results were analyzed statistically by using nonparametric tests. These were undertaken with the aid of "Statistical Package for the Social Sciences" - SPSS, version no. 4 (Nie et al. 1975).

\section{RESULTS AND DISCUSSION}

During the observation period, 55 copulations were recorded. The average frequency of copulation per snail, over $12 \mathrm{hr}$ period, was 3.1 ( $\mathrm{sd}=1.5$; $\min =1 ; \max =7 ; \operatorname{md}=3 ; \mathrm{n}=36$ snails). There were no statistical differences in the frequency of copulation (Table I) between the two albino categories and their pigmented partner (KruskallWallis Test, $\mathrm{P}=0.12$ ).

The two albino categories and the pigmented snails performed the sexual roles (Fig. 1) with similar frequencies (Kruskals-Wallis Test, $\mathrm{P}>0.05$ ). According to Rollinson et al. (1989) it may be wrong to assume that all the snails in a population are equally well-balanced for tendencies to perform the female or male role. For Biomphalaria, is expected that female sexual role be more frequent, as long as they are included among the simultaneous hermaphrodite that practice "Gamete Commerce" (Monteiro \& Dias 1989, Freitas 1994, Dias

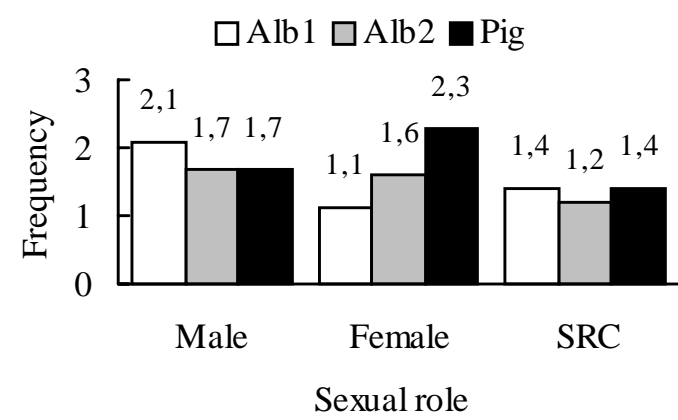

Fig. 1: frequency of the sexual roles performed by snail. n: 12 Alb1 ("good reproducer" albino snails), 12 Alb2 ("bad reproducer" albino snails) and 12 Pig (pigmented snails); SRC: simultaneous reciprocal copulation. 
TABLE I

Descriptive statistics of the frequency of copulation per snail

\begin{tabular}{lccccc}
\hline Snails & Mean & $\mathrm{Sd}^{a}$ & Minimum & Maximum & Median \\
\hline Pigmented & 3.3 & 0.5 & 1 & 7 & 3 \\
"Good reproducers" albinos & 2.9 & 0.4 & 1 & 5 & 3.5 \\
"Bad reproducers" albinos & 2.9 & 0.5 & 1 & 6 & 3 \\
\hline
\end{tabular}

$\mathrm{N}$ : 12 "good reproducers" albino snails, 12 "bad reproducers" albino snails and 12 pigmented snails; $a$ : standard deviation.

1995), a general model of mating systems for simultaneous hermaphrodites that practice cross-fertilization, proposed by Leonard and Lukowiak (1984). The model consists of giving and receiving gametes in alternate and successive parcels. The male or female gamete may be exchanged. However, an association exists between the gamete which will be traded and that which has more risk of loss during the fertilization process. In the case of Biomphalaria, the gametes are subject to an assymetrical risk of damage. The spermatheca is gametolythic (Kitajima \& Paraense 1983) whereas the seminal vesicle phagocytes spermatozoas (Jong-Brink 1969) which may then contribute to the nutrition of receptor snails. The spermatozoa can be considered gametes of risk, and likewise the gamete which will be traded. In our study, the grouping period of $12 \mathrm{hr}$, may not be long enough to observe greater differences between sexual performance among the partners.

On average, the copulation lasted $63.5 \mathrm{~min}$ ( $\mathrm{sd}$ $=56.2 ; \min =5 ; \max =232$ ). Table II shows the descriptive statistics of the duration of copulation/ pair. In molluscans, copulation can last from a few minutes to $12 \mathrm{hr}$, but usually lasts from 30 to 90 min. Simultaneous reciprocal copulations of up to $4 \mathrm{hr}$ were observed in pairs of Helisoma trivolvis (Duncan 1975) and in pairs of B. tenagophila (Dias 1995).

After the snails had been isolated subsequent to being in groups of three, it was found that the production of viable embryos/egg-mass (Fig. 2) and the viability rate $(\mathrm{V} / \mathrm{T}=$ viable embryos/total of eggs) of the "good reproducer" (mean $=7.5$; sd
$=6.5 ; \mathrm{V} / \mathrm{T}=0.49)$ were higher than those of the "bad reproducer" albinos (mean $=0.6$; sd $=1.3$; $\mathrm{V} / \mathrm{T}=0.04)$. This result was similar to that observed before grouping ("good reproducers": mean $=9.5 ; \mathrm{sd}=6.2 ; \mathrm{V} / \mathrm{T}=0.79$, and "bad reproducers": mean $=0.5 ; \mathrm{sd}=0.9 ; \mathrm{V} / \mathrm{T}=0.05)$. A positive relationship between reproductive performance before and after mating was also observed in groups (Freitas 1994) and in pairs of B. tenagophila (Dias 1995).

To relate the copulation behaviour with the reproductive success, we considered only the copulation in which the pigmented snails performed male or male and female roles simultaneously (SRC) in relation to their albino partners (Table III). Of the twelve pigmented snails, eight were

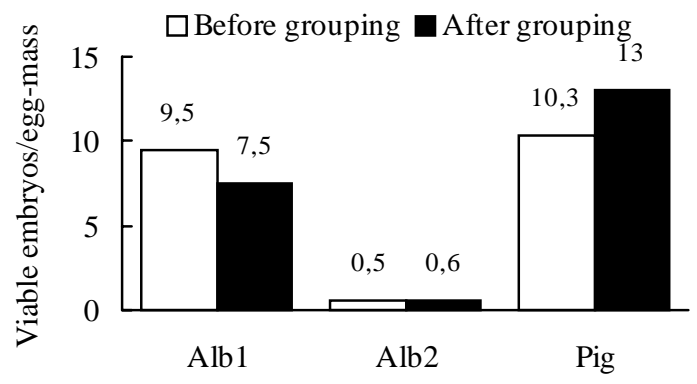

Fig. 2: production of the viable embryos/egg-mass before and after the grouping. n: 12 Alb1 ("good reproducer" albino snails), 12 Alb2 ("bad reproducer" albino snails) and 12 Pig (pigmented snails).

TABLE II

Descriptive statistics of the duration ( $\mathrm{min})$ of the copulation/pair

\begin{tabular}{lcccccc}
\hline Pairs & $\mathrm{N}$ & Mean & $\mathrm{Sd}^{a}$ & Minimum & Maximum & Median \\
\hline Pig and Alb1 & 20 & 58.5 & 61.8 & 5 & 232 & 20 \\
Pig and Alb2 & 20 & 54.8 & 53.4 & 5 & 206 & 20 \\
\hline
\end{tabular}

N: number of copulations; Pig: pigmented snail; Alb1 and Alb2: "good reproducers" and "bad reproducers" albino snails, respectivelly; $a$ : standard deviation. 


\section{TABLE III}

Duration of the copulation between the albino snails and the pigmented partner and production of pigmented embryos/egg-mass per albino snails

\begin{tabular}{|c|c|c|c|c|c|c|c|c|c|c|}
\hline \multicolumn{7}{|c|}{ Duration of the copulation (min) } & \multicolumn{4}{|c|}{$\begin{array}{l}\text { Production of pigmented embryos/ } \\
\text { egg-mass per albino snails (mean } \pm \mathrm{sd})\end{array}$} \\
\hline \multicolumn{4}{|c|}{ "Good reproducers" albinos } & \multicolumn{3}{|c|}{ "Bad reproducers" albinos } & \multicolumn{2}{|c|}{ "Good reproducers" } & \multicolumn{2}{|c|}{ "Bad reproducers" } \\
\hline $\mathrm{R}$ & $\mathrm{SRC}^{a}$ & Female $^{b}$ & Total & SRC & Female & Total & $\mathrm{N}$ & $\begin{array}{l}\text { Embryos/ } \\
\text { egg-mass }\end{array}$ & $\mathrm{N}$ & $\begin{array}{l}\text { Embryos/ } \\
\text { egg-mass }\end{array}$ \\
\hline 1 & 125 & 49 & 174 & 0 & 0 & 0 & 22 & $6.0 \pm 8.4$ & 20 & $0.0 \pm 0.0$ \\
\hline 2 & 0 & 153 & 153 & 0 & 0 & 0 & 18 & $10.7 \pm 6.0$ & 25 & $0.1 \pm 0.4$ \\
\hline 3 & 123 & 109 & 232 & 8 & 0 & 8 & 20 & $2.2 \pm 4.7$ & 18 & $0.0 \pm 0.0$ \\
\hline 4 & 0 & 0 & 0 & 0 & 172 & 172 & 23 & $0.1 \pm 0.4$ & 23 & $0.6 \pm 0.9$ \\
\hline 5 & 0 & 0 & 0 & 206 & 0 & 206 & 27 & $0.1 \pm 0.4$ & 31 & $0.3 \pm 1.1$ \\
\hline 6 & 103 & 0 & 103 & 122 & 0 & 122 & 21 & $0.1 \pm 0.6$ & 25 & $0.6 \pm 1.0$ \\
\hline 7 & 0 & 0 & 0 & 0 & 60 & 60 & 24 & $0.0 \pm 0.0$ & 35 & $0.3 \pm 0.6$ \\
\hline 8 & 0 & 18 & 18 & 32 & 12 & 44 & 22 & $0.1 \pm 0.3$ & 21 & $0.1 \pm 0.3$ \\
\hline 9 & 10 & 30 & 40 & 0 & 19 & 19 & 22 & $0.0 \pm 0.0$ & 24 & $0.0 \pm 0.2$ \\
\hline 10 & 107 & 0 & 107 & 0 & 55 & 55 & 20 & $0.0 \pm 0.0$ & 32 & $0.0 \pm 0.0$ \\
\hline 11 & 79 & 23 & 102 & 0 & 0 & 0 & 24 & $8.5 \pm 7.0$ & 31 & $0.0 \pm 0.2$ \\
\hline 12 & 0 & 0 & 0 & 65 & 7 & 72 & 26 & $0.0 \pm 0.0$ & 18 & $0.7 \pm 2.0$ \\
\hline
\end{tabular}

$\mathrm{R}$ : number of the repetition; $a$ : the albino snails perfomed male and female role simultaneously with the pigmented partner; $b$ : the albino snails perfomed the female role with the pigmented partner; $\mathrm{N}$ : number of egg-masses.

observed in copulation behaviour with their albino partners. Of these eight, three snails (Table III, repetitions no. 1,2 and 11) that copulated exclusively with the "good reproducer" albino snail fertilized their partners, which produced on an average 8.4 pigmented embryos/egg-mass $(\mathrm{s}=7.1 ; \mathrm{n}=64$ eggmass). The other five pigmented snails (Table III, repetitions no. $3,6,8,9$ e 10), that copulated with both partners, transferred none or few spermatozoans to "good" reproducer albinos that produced at maximum an average of 2.2 pigmented embryo/ egg-mass. Thus, "bad reproducers" might have caused a decrease in the cross-reproduction performance by "good reproducers".

There is an absence of sperm transference (sterile copulation) in the great majority of unilateral copulations and there is sperm transference (fertile copulation) in the great majority of reciprocal copulations in pairs of B. tenagophila (Dias 1995). In addition, 64 to $100 \mathrm{~min}$ of copulation are necessary for sperm transference to occur in unilateral copulations. In simultaneous reciprocal copulation, 80 to $144 \mathrm{~min}$ are necessary for at least one partner to transfer sperm to the other (Dias 1995). Hence, concerning the duration of copulation, the "good reproducer" albino snails from repetitions no. 3, 6 and 10 (Table III) had the same opportunity to be fertilized by the pigmented partners as the "good reproducer" albinos from repetitions no. 1, 2 and 11 (Table III). Therefore, the pigmented snail may have changed partners due to a lack of success in spermatozoan transference with the pre- vious partner. The pigmented snail that copulated only with the "good reproducer" partner, as male and/or as male and female simultaneously, might have an advantage in reproductive success.

\section{ACKNOWLEDGEMENTS}

To Dr Mara Lucia Ferreira Dias, to Dr José Rabelo de Freitas and to anonymous referee for criticism and suggestions.

\section{REFERENCES}

Dias MLF 1995. Padrões comportamentais da reprodução de Biomphalaria tenagophila (Orbigny) (Mollusca, Planorbidae). PhD Thesis, Universidade de São Paulo, São Paulo, 119 pp.

Duncan CJ 1975. Reproduction, p. 309-365. In V Fretter \& J Peake (eds). Pulmonates. Academic Press. London.

Freitas JR, Resende ES, Junqueira DV, Costa AM, Pellegrino J 1975. Criação em massa e ritmo de crescimento da Biomphalaria glabrata. Ci Cult 27: 968-974.

Freitas JS 1994. Dinâmica de genes e estratégias reprodutivas em grupos de Biomphalaria tenagophila (Orbigny) (Mollusca, Planorbidae). PhD Thesis, Universidade de São Paulo, São Paulo, 118 pp.

Hofmann PRP 1987. Aspectos da biologia e do polimorfismo enzimático em três espécies do gênero Biomphalaria. PhD Thesis, Universidade de São Paulo, São Paulo, 117 pp.

Jong-Brink M 1969. Histochemical and electron microscope observations on the reproductive tract of Biomphalaria glabrata (Australorbis glabratus), intermediate host of Schistosoma mansoni. Z Zellforsch 102: 507-542. 
Kitajima EW, Paraense WL 1983. The ultrastructure of the spermatheca of Biomphalaria glabrata (Gastropoda, Pulmonata). J Morphol 176: 211-220.

Leonard JL, Lukowiak K 1984. Male-female conflict in a simultaneous hermaphrodite resolved by sperm trading. Am Nat 124: 282-286.

Monteiro W, Dias BFS 1989. Estratégias reprodutivas em Biomphalaria (Mollusca, Planorbidae). Ci Cult 41: 1051-1054.

Newton WL 1954. Albinism in Australorbis glabratus. Proc Helminthol Soc Wash 21: 72-74.
Nie NH, Null CH, Jenkins JG, Steinbrenner K, Bent DH 1975. SPSS - Statistical package for the social scienses, 2 ed., MacGraw Hill, New York, 675 pp.

Paraense WL 1955. Autofecundação e fecundação cruzada em Australorbis glabratus. Mem Inst Oswaldo Cruz 53: 277-283.

Rollinson D, Kane RA, Lines JRL 1989. An analysis of fertilization in Bulinus cernicus (Gastropoda: Planorbidae). J Zool (Lond) 217: 295-310.

Rudolph PH, Bailey JB 1985. Copulation as female and use of allosperm in the freshwater snail genus Bulinus (Gastropoda: Planorbidae). J Moll Stud 51: 267-275. 